\title{
Cutaneous Angiosarcoma in Face
}

\author{
Ho Youp Kim ${ }^{1}$, Hong Kyoung Lee ${ }^{1}$, Seung Hoon Woo ${ }^{1,2}$ and Jin Pyeong Kim ${ }^{1,2}$ \\ ${ }^{l}$ Department of Otorhinolaryngology, ${ }^{2}$ Institute of Health Sciences, School of Medicine, Gyeongsang National University, Jinju, Korea
}

\section{콧등에 발생한 피부혈관육종 1 예}

김호엽 ${ }^{1} \cdot$ 이홍경 $\cdot$ 우승훈 ${ }^{1,2} \cdot$ 김진평 ${ }^{1,2}$

경상대학교 의학전문대학원 이비인후과학교실, ${ }^{1}$ 건강과학연구원 ${ }^{2}$

\author{
Received February 1,2010 \\ Revised April 5, 2010 \\ Accepted May 11,2010 \\ Address for correspondence \\ Jin Pyeong Kim, MD \\ Department of Otolaryngology, \\ School of Medicine, \\ Gyeongsang National University, \\ 90 Chiram-dong, Jinju 660-702, Korea \\ Tel $+82-55-750-8175$ \\ Fax +82-55-759-0613 \\ E-mail jinpyeong@gnu.ac.kr
}

A cutaneous angiosarcoma is a rare, aggressive malignancy with a poor prognosis, with only a few cases of it in head and neck have been reported. In the present case, we reported a primary angiosarcoma of the nasal dorsum in a 70-year-old man without prior irradiation of head and neck region. The authors reviewed the literature and discussed treatment and prognosis of cutaneous angiosarcoma in nasal dorsum.

Korean J Otorhinolaryngol-Head Neck Surg 2010;53:383-5

\section{서 론}

두경부의 피부혈관육종은 혈관에서 기원하여 피부의 진피 층 내에 발생하는 종양으로 전체 육종의 $1 \%$ 에 해당하고 이 중 50\% 이상이 두경부에 발생한다. ${ }^{1,2)}$ 전형적인 임상양상 없 이 증상이 비특이적이고 경부에 생기는 장미증(rosacea), 얕은 연조직염(erysipelas), 연조직염(cellullitis), 혈관신경 부종(angioneurotic edema) 같은 감염성 질환으로 오진되 는 경우가 많은 것이 특징이다. ${ }^{3)}$

치료는 외과적 광범위 절제술 후 방사선 및 화학적 항암 치료를 필요로 하지만 높은 전이능력 때문에 5년 생존율이 10 20\% 밖에 되지 않는다고 보고되고 있다. ${ }^{4)}$ 저자들은 조 직검사상 콧등에 피부혈관육종으로 진단된 1 예를 수술적 치 료 및 방사선 치료 후 경과관찰 중이기에 문헌고찰과 함께 보고하는 바이다.

\section{증 례}

70세 남자 환자로 방사선 치료, 외상, 과도한 일광노출의 과거력이 없었으나 6 개월 전부터 콧등에 만져지는 $1.5 \mathrm{~cm}$
의 검붉은색 종물을 주소로 내원하였다(Fig. 1A). 부분 마 취하에 절개생검을 시행하여 피부혈관육종으로 진단되었다. 경부 전산화단층촬영, 복부 초음파, 뼈스캔, 양전자 방출 단 층촬영술 $(\mathrm{PET}-\mathrm{CT})$ 등의 전이검사를 하여 전이 소견이 없 음을 확인하고(cT1NOMO) 외과적 단순 절제술(Fig. 1B) 및 전외측 대퇴부 유리피판술(anterolateral thigh free flap) 시행하였다(Fig. 1C).

조직병리학검사상 절제선에선 피부혈관육종이 관찰되지 않았지만 종물은 비전형적인 혈관 내피세포로 구성된 혈관 들이 서로 문합되는 특징 (Fig. 2A)을 보이고, 면역화학염색 $\mathrm{CD} 31, \mathrm{CD} 34$ 에서 양성을 나타내어 피부혈관육종으로 진단 하였다(Fig. $2 \mathrm{~B}$ and $\mathrm{C}$ ). 술 후 병기에는 변화는 없었으며 절 제선은 병리학적으로 침범이 없음을 확인하였다. 술 후 방사 선 치료 $(6,080 \mathrm{cGy})$ 를 시행받고 퇴원 후 3 개월 간격으로 정기적으로 외래 내원하여 이학적 검사를 시행하고 6 개월 간 격으로 경부 전산화단층촬영 및 양전자 방출 단층촬영술 $(\mathrm{PET}-\mathrm{CT})$ 로 경과관찰 중이며 검사 결과 국소 및 전신전 이를 보이지 않아 18 개월 동안 외래에서 재발 없이 추적관 찰 중이다. 

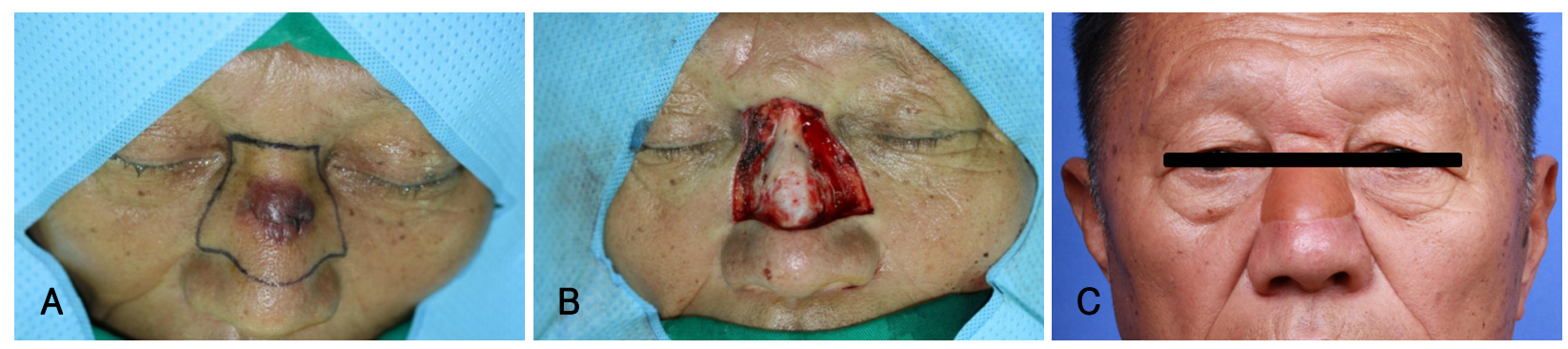

Fig. 1. Pre-operation photograph shows blue patch over the nasal dorsum with yellow discharge of the cutaneous angiosarcoma (A). After surgical excision of the cutaneous angiosarcoma (B). 18 months after operation (C).
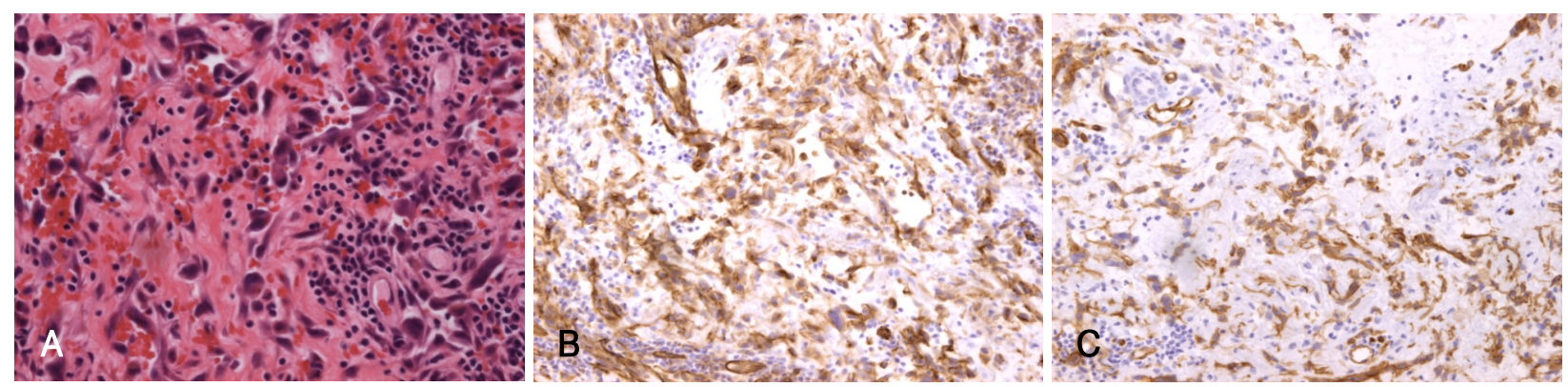

Fig. 2. Microscopic histopathologic findings. Irregular vessel anastomosing channels lined by smooth endothelial cell is noted (H\&E stain, $\times 40)(A)$. Immunohistochemical staining for CD31 in tumor cells are strong positive $(\times 100)(B)$. Immunohistochemical staining for CD34 in tumor cells are focal positive $(\times 100)(C)$.

\section{고 찰}

피부혈관육종은 전체 육종의 $1 \%$ 미만으로 약 $50 \%$ 가량 이 두경부에 발생한다. ${ }^{1,2)}$ 가장 호발하는 부위는 두피 및 상 부 안면부이다. 주로 70 세 이상의 백인 남자에게 호발하며 동양인에서는 드물다. ${ }^{5)}$

발생 원인은 정확히 알려져 있지 않지만 일광노출, 방사선 조사, 외상, 염화비닐(vinyl chloride), 비소(arsenic)와 관 련이 있다는 보고가 있고 ${ }^{6)}$ 그 중 가장 흔히 강조되는 위험인 자는 두경부의 방사선 조사 경력이다.

보통의 진찰결과 진단이 늦어지는 경우가 많은데 이유는 임상양상이 비특이적이고 다양하며, 조직학적인 진단이 까 다롭기 때문이다. 보고된 임상양상은 푸른색 병변, 보라색 결절 혹은 가피, 만성 부종, 연조직염, 피부 궤양 등 전형적 인 임상양상을 구분 짓기는 어렵다. ${ }^{3)}$

조직학적으로는 종물은 평탄한 내피세포와 불규칙한 혈관 문합으로 구성되어 있고 세포질, 다형태성, 유사분열 능력에 따라 경도(low), 고도(high) 분화(grade)로 구분할 수 있 다. ${ }^{7)}$ 경도분화 피부혈관육종은 평탄한 내피세포와 불규칙한 혈관 문합으로 구성되어 있고, 고도분화 피부혈관육종은 다 형성의 방추세포 혹은 분열능력이 뛰어난 내피세포를 가진 것이 특징이다. ${ }^{7,8)}$

피부혈관육종의 진단에는 조직학적인 특징 외에도 면역 화학염색이 도움이 되며, 종양세포는 Factor VIII associated antigen, UEA-1, CD31, CD34 등과 같은 내피세포 표지 자에 양성을 나타낸다. ${ }^{9}$ 혈관육종의 기원세포가 혈관 내피세 포인지에 대한 논란이 있으나, 혈관 내 적혈구의 존재, $\mathrm{CD}-$ 31 및 CD34의 발현이 좀 더 혈관 내피세포에서 유래했음 을 시사한다. 따라서 CD31, CD34가 피부혈관육종에 가장 특이적인 표지자이다.

아직까지 피부혈관육종은 발생빈도가 드물어 체계적인 치 료 방법이 확립되어 있지 않고 병기 설정 방법이 정립되어 있지 않다. 일반적으로 피부혈관육종의 치료는 광범위 외과적 절제와 추가로 방사선치료를 병행하는 방법이 사용되고 있 는데 방사선치료는 $6,000 \sim 7,000 \mathrm{cGy}$ 조사가 필요하며, 7,10$)$ 항암치료는 Doxorubicin이 가장 효과가 있는 항암제로 보고 되어 있다. ${ }^{11,12)}$

피부혈관육종의 예후는 평균생존기간이 10.5 20개월로 알려져 있고 5년 생존율은 $12 \%$ 로 알려져 있다. ${ }^{413)}$ 생존율 이 낮은 이유는 국소 재발 및 원격전이가 흔히 발생하기 때 문이며 상대적으로는 국소재발 빈도가 높아 예후가 불량해 진다. ${ }^{12)}$ 여러 연구 결과 예후에 영향을 미치는 인자는 연령, 성, 종양의 위치, 임상적 양상 등이 거론되었지만 치료결과 에 가장 큰 영향을 끼치는 인자는 수술적으로 광범위 절제와 전이가 없는 안전한 절제선을 확보하는 것이다. ${ }^{1,7,14)}$

안전한 절제선을 확보하고 절제한 후에는 병변의 재건을 위하여 피판술을 이용하는데 국소 재발을 하는 피부혈관육 종의 특성상 섬피판(island flap) 보다는 수술 부위를 유리피 
판술(free flap)을 시행해야 하기 때문에 전외측 대퇴부 유 리피판술(anterolateral thigh free flap)과 요측전완피판 (radial forearm free flap)이 주로 사용된다. 저자들은 환 자의 병변이 크지 않아 안전한 절제를 시행한 후 피판의 두 께가 얇은 요측전완피판을 사용할 계획이었으나 환자가 팔 을 많이 사용하는 직업이므로 팔의 유동성을 고려하여 전외 측 대퇴부 유리피판술을 시행하였다. 이와 같이 안면부의 피 부혈관육종은 다른 감염성 질환들과 임상양상이 비슷하여 진단이 늦어져 불량한 예후를 보이기 때문에 조기진단이 중 요하다. ${ }^{6)}$ 그러므로 50세 이상 환자에서 두경부에 외상없이 피부가 검붉은 색으로 변하고 병변의 크기가 증가하면 피부 혈관육종을 의심하고, 가능한 빨리 조직검사 및 면역화학검 사를 통해 확진하여야 한다. 저자들은 환자의 병변이 안면부 의 중앙인 콧등에 병변이 존재하고 조직학적 검사상 경도 분 화를 보이므로 예후가 양호할 것으로 예상하고 ${ }^{15)}$ 단순 절제 술 시행 후 안면부 방사선 조사를 통해 치료하였다. 술 후 미 용적으로나 기능적으로 만족하는 결과를 얻었으며 18 개월간 외래 경과 관찰 중에 시행한 이학적 검사 및 경부 전산화단 층촬영, 양전자 방출 단층촬영술상 특이 소견은 보이지 않았 다. 외래 추적관찰 시에는 국소재발 및 폐와 간 등에 원격 전이가 흔한 피부혈관육종의 특징을 고려할 때 3 개월 간격 으로 외래 추적관찰시 이학적 검사를 시행하고 특별한 이상 이 없는 경우 6 개월 간격으로 경부 전산화단층촬영, 양전자 방출 단층촬영술을 시행하는 것이 유의할 것으로 사료된다. 결론적으로 안면부에 발생한 피부혈관육종은 가능하면 안 전선을 $2 \mathrm{~cm}$ 이상 확보하는 광범위 외과적 절제술 후 방사 선 및 항암치료를 통한 적극적인 치료가 중요하겠지만 병변의 크기가 작으며 조직학적 분화도가 경도이고 절제면의 안전 성을 확보할 수 있다면 환자의 미용적, 기능적 부분을 고려 한 접근이 적절할 것으로 사료되어 저자들은 단순절제술 및 방 사선 치료를 시행하고 이에 문헌고찰과 함께 보고하는 바이다.

\section{REFERENCES}

1) Morrison WH, Byers RM, Garden AS, Evans HL, Ang KK, Peters LJ. Cutaneous angiosarcoma of the head and neck. A therapeutic dilemma. Cancer 1995;76 (2):319-27.

2) Hodgkinson DJ, Soule EH, Woods JE. Cutaneous angiosarcoma of the head and neck. Cancer 1979;44 (3):1106-13.

3) Cannavò SP, Lentini M, Magliolo E, Guarneri C. Cutaneous angiosarcoma of the face. J Eur Acad Dermatol Venereol 2003;17 (5) :594-5.

4) Aust MR, Olsen KD, Lewis JE, Nascimento AG, Meland NB, Foote $\mathrm{RL}$, et al. Angiosarcomas of the head and neck: clinical and pathologic characteristics. Ann Otol Rhinol Laryngol 1997;106 (11):94351 .

5) Fury MG, Antonescu CR, Van Zee KJ, Brennan MF, Maki RG. A 14-year retrospective review of angiosarcoma: clinical characteristics, prognostic factors, and treatment outcomes with surgery and chemotherapy. Cancer J 2005;11 (3):241-7.

6) Pawlik TM, Paulino AF, McGinn CJ, Baker LH, Cohen DS, Morris JS, et al. Cutaneous angiosarcoma of the scalp: a multidisciplinary approach. Cancer 2003;15:98 (8):1716-26.

7) Russel WO, Cohen J, Enzinger FM, Hajdu SI, Heise H, Martin RG, et al. A clinical and pathologic staging system for sarcoma. Cancer 1977;40:1562-70.

8) Wenig BM. Atlas of Head and Neck Pathology. Philadelphia: W.B. Saunders, 1993. p.88-9.

9) Mackay B, Ordóñez NG, Huang WL. Ultrastructural and immunocytochemical observations on angiosarcomas. Ultrastruct Pathol 1989; $13(2-3): 97-110$

10) Reed RJ, Palomeque FE, Hairston MA 3rd, Krementz ET. Lymphangiosarcomas of the scalp. Arch Dermatol 1966;94 (4) :396-402.

11) Liu AC, Kapp DS, Egbert B, Waters L, Rosen JM. Angiosarcoma of the face and scalp. Ann Plast Surg 1990;24 (1):68-74.

12) Nagano T, Yamada Y, Ikeda T, Kanki H, Kamo T, Nishigori C. Docetaxel: a therapeutic option in the treatment of cutaneous angiosarcoma: report of a patients. Cancer 2007;110 (3):648-51.

13) Mendenhall WM, Mendenhall CM, Werning JW, Reith JD, Mendenhall NP. Cutaneous angiosarcoma. Am J Cli Oncol 2006;29(5): 524-8.

14) Mark RJ, Tran LM, Sercarz J, Fu YS, Calcaterra TC, Juillard GF. Angiosarcoma of the head and neck. The UCLA experience 1955 through 1990. Arch Otolaryngol head Neck Surg 1993;119 (9) :973-8.

15) Köhler HF, Neves RI, Brechtbühl ER, Mattos Granja NV, Ikeda MK, Kowalski LP. Cutaneous angiosarcoma of the head and neck: report of 23 cases from a single institution. Otolaryngol Head Neck Surg 2008; $139(4): 519-24$. 